\title{
COMMENTARY: WHITHER AFTER COVID-19 AND BREXIT: A SOCIAL SCIENCE PERSPECTIVE
}

\author{
Jagjit S. Chadha*
}

National Institute of Economic and Social Research, London, United Kingdom

${ }^{\star}$ Corresponding author. E-mail: j.chadha@niesr.ac.uk

'..to carry out research into the economic and social forces that affect people's lives and to improve the understanding of those forces and the ways in which policy can bring about change'.

On the establishment of the National Institute of Economic and Social Research in 1938.

100,359, Cumulative confirmed Covid-19 deaths in the UK, Our World in Data, 26 January 2021

Royal Assent for European Union (Future Relationship) Act granted on 31st December 2020.

The country is facing the twin traumas of managing two exits. Exit from the Covid-19 crisis and from the European Union. Of course, much of the world is dealing with the first and the European Union has also had the latter with which to contend. But the United Kingdom is set to lose permanently some 5-8 per cent of national income as a result of the scarring from these events. There can be little doubt that it is a dire moment in our national history. But as well as permitting statements that allow us to calibrate the impact of extraordinary events such as these, how can social science help us understand the nature of these shocks and provide policy ideas to mitigate their effects? In the spirit of NIESR's Beveridge-inspired objective, this Commentary provides suggestions and argues for a more resilient and robust ${ }^{1}$ socioeconomic eco-system. By resilience I mean an economic structure that can return to stability in response to shocks and by robustness choosing a set of policy choices that are not undermined by the simple observation that any single model (or view) is a rough approximation. Such an eco-system will have to run from growing the capacity for basic to applied research all the way to building receptacles for the output in media and government, as well as the development of mechanisms to ensure that government builds robust policy on cultivated, expert insight.

\section{The traumas}

The lockdowns in England (23 March, 5 November, 4 January), as well as those in the devolved regions, associated with Covid-19 and the persistent question marks placed on our methods of 'getting and spending' have not only triggered large falls in economic activity, as measured by GDP. ${ }^{2}$ The spread of the virus has also called for a switch from socially intensive private sector activities such as hospitality, leisure and restaurants to the provision of public sector support in health, education, social care and communication networks. And our exit from the European Union after the end of the transition period on 31 December 2020 is with a Trade and Co-Operation Agreement that opens a huge policy gap in every area of economic, social, security and foreign policy that was explored by the Policy Reform Group for NIESR in 2019. While this policy gap is not insurmountable, it does require imagining and

\footnotetext{
${ }^{1}$ See Hansen and Sargent (2011) on robustness.

${ }^{2}$ From The World is Too Much With Us, William Wordsworth. We can also question the GDP measures quite markedly, see Chadha and Dixon (2020).

${ }^{3}$ The EU-UK Trade and Cooperation Agreement at https://ec.europa.eu/info/relations-united-kingdom/eu-uk-trade-andcooperation-agreement_en, accessed on 10 January 2021.
}

(c) National Institute Economic Review 2021. 
implementing a consistent process of structural reform over several years that confronts the key conceptual issues of filling gaps. So unlike the 1980s, which were more concerned with deregulating product, labour, financial markets, it is now much more about addressing specific capital gaps-human, organisational and knowledge-which in my view also finally have to deal with the 90-year old 'Macmillan Gap' in finance. ${ }^{4}$

The calculation of economic losses from these two exits reflects a scientific consensus, stated well by the Office for Budget Responsibility in November 2020, and should be used as a starting point for formulating responsible policies in mitigation. Given the body of research, dither and delay is not helpful and rather more understanding and action to mitigate is required from the government. In the former case, exit from the Covid-19 crisis needs to address the loss of firm specific knowledge and the slow re-orientation of the economy, which has some 10-15 per cent of employees working in industries acutely vulnerable to Covid-19, to digital service and public good provision when there happens to be a limited initial pool of people to work in these areas. The costs of EU exit result from the compression of trade with a large wealthy partner, who also happens to be a neighbour, that will prevent the full force of trade through gravity to work, as well the enduring uncertainty of reaching substantive agreements on trade in capital, labour, goods and services with each of the key trading blocs in the rest of the world. Holmes et al. (2016) provided some measure on the task ahead: '[A]fter Brexit...there still remain 56 potentially live negotiations. As a benchmark, the European Commission is currently engaged in 10 active trade negotiations'. This uncertainty over the nature of final agreements on trade will tend to lead to firms delaying investment. And as Venables (2020) shows it is very hard for regions to regain their internationally competitive advantage once lost, particularly if there are agglomeration effects at work. If not addressed by prompt policy response, regions may fall into the sump of a low-wage, low-skill and low-growth future. While we can agree that certain regions are not able to participate sufficiently in international markets and wish to address that by 'leveling up', we do not have a working definition of what that would require and when we would know that we have succeeded or failed (Besley, 2020).

\section{Current policy issues}

A pandemic such as Covid-19 threatens both life and quality of life as well as disrupting conventional social and economic practice. In fighting this crisis, the government needed first to define its objectives. Let me suggest that it was to limit the spread of the virus and the peaks in the waves of infection and, subject to that, to limit the long run impact on well-being and income across regions and households. It then needed to work out what instruments it had at its disposal to contain the spread. These ranged from lockdowns of various degrees of severity, to the development of healthcare capacity (especially ICU), to extensive fiscal support for families and firms suffering income losses from the pandemic. There remain significant question marks over the extent of the safety net for poorer families and it is with some regret that earlier more consistent approaches were not made to tackle child poverty through free school meals or a temporary enhancement of child benefit or the introduction of a family tax allowance. The instruments would have to reflect the structure of an open economy with high levels of labour mobility. It then needed to communicate its objectives and responses in such a manner that people understood and agreed with them so that they would behave in a way compatible with the central objectives. Work by Ajzenman et al. (2020) and Albornoz et al. (2020) illustrate the powerful signalling effects of leaders' statements and actions on individual behaviour and the tendency of behaviours to conform with widely understood social norms. Taken together this type of work implies that consistent statements and actions by policymakers would have led to greater adherence to lockdown plans. The eagerness to end lockdowns

\footnotetext{
${ }^{4}$ The ESRC's largest ever investment in the creation of The Productivity Institute based at the Alliance Business School at the University of Manchester is investigating how to bring this about. The Macmillan Committee on Finance and Industry reported in June 1931 arguing inter alia for more funding for small businesses, see Stamp (1931).
} 
or to excuse some behaviours may have reduced the efficacy of the measures and led to a greater incidence of virus infections when lockdown measures were relaxed. ${ }^{5}$

One issue that emerged time and time again was the trade-off involved in using lockdown as an instrument of economic policy that reduced overall activity in order to save lives. Indeed, at one extreme, Miles et al. (2020) argued that the output lost from lockdowns would be unlikely under any reasonable scenario to match the economic value of lives saved. For example, a 10 per cent loss of GDP, implying income forgone of some $£ 200$ bn, would break even if lockdowns saved 10 years of life, at $£ 30,000$ per quality adjusted year of life saved, for some 6-700,000 people. While a useful benchmark calculation, it cannot accurately capture the possible impact on long-term health from the emergence of long Covid-19 (rather than deaths per se), ${ }^{6}$ the loss of lives elsewhere that might have resulted from an overload of the health system, the impact on the income distribution from a more rapid spread of the virus as opposed to the socio-economic impact from lockdowns per se. While lockdowns, with their sharp falls in national income, have affected poorer households more abruptly, with perhaps a doubling of destitution in sight (Bhattacharjee and Lisauskaite, 2020), it is also exactly those households that would suffer from a rapid escalation in the infection rate, as households with lower wages (or skills) were more likely to work in the service sectors acutely exposed to Covid-19. Exploiting any short run trade-off should be designed simply to smooth the spread of the virus and importantly aim to retain a sense of credibility in management of the pandemic and thus seek to allow a level of social interactions at some safe level. Recall as well that households and firms have access to their own information, however heuristic, about the risk of the virus so its spread would have in any case led to considerable endogenous social distancing (Toxvaerd and Makris, 2020) that would have affected the economy anyway. And so, in recognising that the economy and health move in lockstep, and that there is no long run trade-off, a failure to control the virus would ultimately undermine any recovery. Therefore, to any short run calculus one must add some long run notion of a healthy society that allows the development of prosperity.

And if we move beyond simple arithmetic, we also need to confront uncertainty. And given the uncertainties about whether a vaccine could be discovered, effectively rolled out and the long run impact of Covid-19 on health, it would have been sensible to be cautious in any relaxations of these measures. In fact, one of the major insights from recent social science is the prevalence of uncertainty as opposed to identifiable risk, which then affects decisions in a critical manner (Knight, 1921). There can be uncertainty across many dimensions but specifically it is over the outcome of an event on which we cannot place a specific probability. In this sense, the uncertainty over the vaccine rollout involves a sequence of events about which we cannot be sure: discovery, effectiveness, physical capacity to inoculate and the propensity for viral mutations as well as the needs for repeated future rounds of vaccinations. As well as the spread of the virus, the scale of uncertainty and its asymmetry (we should worry more about the escalation in the virus than its abeyance) itself should be key factors in driving policy decisions.

Once we then realise the tendency for the virus to grow exponentially and add to that the uncertainty over its impact and our ability to deploy an effective vaccine, early lockdowns, clearly communicated, would have helped. Harvey (2020) suggests that entering lockdown 1 week earlier in March would have reduced the peak of infections by some 50 per cent and, along with it, the number who died. Not announcing a lockdown during October half-term and instead signaling some liberalisation in the restrictions in the run-up to Christmas was neither consistent with the objectives nor tenable, with decisions quickly being reversed later and therefore at some cost to the rate of infection.

The Coronavirus Job Retention, or furlough, Scheme is a further case in point. It was first announced in March and originally due to be wound down at the end of May and then June and subsequently at the Summer Statement in July it was prolonged to the end of October. At the start of the November lockdown the furlough scheme was further extended to December and then to the end of March. And then on

\footnotetext{
${ }^{5}$ See, for example, Michael Dobbs in The Telegraph, “The day Dominic Cummings broke a nation's trust by going for a drive," 20 December 2020.

${ }^{6}$ Ayoubkhani et al. (2021) in indicative work highlight the long-term risks to health from Covid-19 infections by examining organ specific impairment compared to a control group.
} 
17 December, it was extended to the end of April 2021. While the extensions have been welcome and recognise the time that any adjustments to a post-Covid-19 economy will take, firms and workers have had to contend with a moving end date that provided a hard constraint over the summer. The policy would have been more effective if it had eliminated the time dimension and the possibility of expiry and offered a commitment that ran contiguously with the control of the virus. ${ }^{7}$ With the expiry of the EU transition period looming at the end of December bringing with it the need for a final deal to be agreed, critically difficult questions arising from Covid-19 not only created a lack of bandwidth for policymakers but probably also acted to limit further the impact of jobs support. Indeed, an open question is the extent to which planning for EU exit hampered pandemic planning.

How ought we to bring all these points together to motivate the deployment of social science? There are a number of clear steps in working through a plan. Set or explain our objectives. Understand the socio-economic structure about who is affected, that there are both possibilities of exponential growth in the virus and in permanent losses in some sectors. Also recognise the uncertainties inherent in understanding the impact and duration of the crisis. Recognise that we have limited instruments to deal with the virus spread. Accept and explain some economic losses but also understand that virus control is a necessary condition for recovery.

A good plan for dealing with Covid-19 would have been to make statements to the effect that there was going to be state contingent support for firms and labour, including sick-pay, develop a credible test, trace and tracking system (involving subsides for firm-led testing, as well as workforce rotations), the ramping up of health, social care and support for mental health (coupled with greater devolution to local levels where knowledge is less imperfect) and to admit that there were going to be ongoing restrictions on internal and external movement, including mandatory tests for those arriving at UK ports and airports, as well as imposing limits on international movement per se. While the benefits from opening schools and universities would be largely accrued by future generations, they could have been more obviously swapped for more control over the opening in the hospitality sector and thereby limiting the increase in the reinfection rate. In fact, the sectoral questions were the real trade-offs to be addressed. An interesting question is whether the calibrations of the relaxation were affected by lobbying from the hospitality sectors. The regional and local issues of the spread of the virus can be addressed by offering granular and timely data but also checking that data against evidence from sampling individuals for the virus, evidence from serology as to whether they had anti-bodies and from examining sewage. ${ }^{8}$ What seems to be have been absent at various critical stages is a strategy that promoted testing, ${ }^{9}$ checking and the provision of appropriate local healthcare and then sending prompt and clear messaging on lockdown measures with clarity of the extent of ongoing fiscal support. Understanding the relative success in the rollout of the vaccines in the UK since December 2020 underlines rather than undermines many of these points as that was built on 'centralised NHS, strong planning and willingness to spend bring success following crisis problems'. ${ }^{10}$ In fact, pandemic and Brexit policy has, at times, looked like an attempt to portray tactics as a strategy.

\section{How social science helps}

If I may turn to history momentarily, a discussion between Robert Fogel, a quantitative economic historian, and Geoffrey Elton, an administrative historian, in 1983 is instructive. Having been somewhat wary of each other's approaches in the 1960s, by the time of this debate they had developed a common

\footnotetext{
${ }^{7}$ Alloza (2016) looks at the relationship between the effectiveness of fiscal policy in recession and under uncertainty more formally.

${ }^{8}$ See the Royal Society's DELVE initiative (2020, various) and also the POST report on monitoring wastewater (December 2020). Chadha (2020a) discusses how economics can help in a health crisis.

${ }^{9}$ While there a valid issue over the power of any tests, it is also the case that more frequent testing would increase the power of even a weak test. See Ramdas et al. (2020).

${ }^{10}$ Financial Times, 'Centralised NHS, strong planning and willingness to spend bring success following crisis problems', 18 January 2021.
} 
view that the quality of historical analysis depended on the 'provenance, domain and reliability of the evidence'. Indeed, a narrative without a foundation in accurate detail can be challenged in its interpretation. If history is the unbiased study of the past, then social science must be the unbiased study of current society but with the further aim to change it for the better. The economist would couch such an aim as changing path of progress because the straight line of future prosperity is far from pre-determined. But it will depend on clear analysis of the facts and 'an understanding of the causes of things'. ${ }^{11}$

And this where social science can clearly help. Lupia (2017) provides four core principles for social science. First, we need rigour. By which we provide a clear outline of how we know what we say we know. It must emerge from ethical foundations that underpin a genuine concern for solving real world problems. Without wishing to be excessively utilitarian one might adopt some view of ethical ends involve some hat tip to maximisation of utility, increase individual rights and freedoms, or pursue the common good and give people a share of the good life. To achieve this social science must demonstrate precision in measurement and conceptualisation. And finally, it must also strive to convince on causality.

Much of the best work, as showcased by the various festivals of social science (e.g., those in this Review), encompass these principles. But there is more to be done. Because social science deals with the everyday and commonplace: the school, the workplace, the household, there is a specific risk that valuable insights may be challenged by personal experiences or reflections. In some senses, such a challenge is no bad thing as anyone receiving advice needs to internalise its consequences. But recall that even simple intuition is often a hard-won logic that displaced a view led by experience and typically a rule of thumb. Take the intuitive idea, for example, that a minimum wage would raise unemployment and confront that with the outcome that it tended to support both employment and labour income. ${ }^{12}$

Brewer (2013) reminds us that social science involves the study of society, an examination of the way that its people behave and are both influenced by and influence others. Society is of course a collection of individuals, groups and institutions. And in our specific way we belong to each but not in some fixed way because over time and across generations society and our place in it will evolve. And so social science then extends to the whole eco-system of relationships. In order to then understand the host of contemporary issues, we need social science. And this extends not only to understand forces but also human responses and how we can improve outcomes. Public social science must therefore seek to inform policy in order to have public value.

\section{Public understanding of social science}

Let us start with what we now know that we should use to guide our future path:

- The health and the economy do not represent two elements of a trade-offs but are inextricably linked with health acting as a constraint on economic prosperity;

- Uncertainty over policy and ambiguity in communication hamper the effectiveness of policy initiatives;

- While contractions and recessions promote some re-orientation of resources to a new structure, they tend to amplify existing inequalities;

- Economic adjustment in goods and labour markets takes time, which may be a significant fraction of any one individual's lifetime.

- Prosperous economic futures depend on current access to high-quality education and training;

- There is much more fiscal space to provide public insurance and drive the economy onto a different path than we thought a decade or so ago;

- The monetary framework has worked well in anchoring inflation and ensuring market liquidity.

\footnotetext{
${ }^{11}$ The Beveridge-inspired motto of the LSE from Virgil is rerum cognoscere causas.

${ }^{12}$ See Low Pay Commission (2020) for a summary.
} 
If these observations are broadly accepted, we can move onto planning for national recovery following EU exit and the end of the pandemic. And that centers on the role of public policy, particularly fiscal policy, in shaping that recovery over the medium term. While the focus of fiscal policy has been on limiting expenditure or searching for value for money, or public sector productivity, it is also the case that fiscal policy needs to address genuine gaps in the provision of public goods and develop better mechanisms for allocating across alternate priorities. ${ }^{13}$ Policy cannot be driven by the pursuit of soundbite. There are two quite distinct issues here. One concerns the production of analysis and advice and ensuring that it is absorbed. The second is how government policy is then assessed and placed under independent scrutiny. Admittedly, most of our national debate occurs in the media and we are fortunate to have a well informed and able media. But the media tends mostly to scratch the surface, as broadcasts and newspapers are to some extent ephemeral. That debate also needs to have the addition of more formal scrutiny of government policy. Large number of reports are produced by the government, often by world-leading experts and they are often of very high quality. And the National Audit Office (2020) has regularly produced authoritative analyses of policy, for example, its critical report on the failures of test and tracing. But other than ensuring the reports get some mention in the media how can we ensure that they are absorbed into the sausage-making factory that is policy? The exchange of soundbites at Prime Minister's Question Time is surely no longer enough. ${ }^{14}$

Parliamentary Committees hold inquiries and produce analyses based on expert advice and the input from special advisers. But the reports do not tend to have formal or considered response from government. We could certainly move further in insisting on a formal response with timelines in response to these reports. The pressure to reform fiscal policy requires the adoption of a formal timetable for Budgets and Spending Reviews and an increase in the analysis of fiscal policies to explain both its short and long run impact, as well as on the distribution of income and regional disparities. Rather than announcing as fait accompli, it would seem sensible to a system of White or Discussion Papers that would invite expert comment on tax or spending policies. Academics must be further encouraged to be involved in these processes by their universities and the next Research Excellence Framework.

Indeed, there is a further step. The 60 plus members of Scientific Advisory Group for Emergencies first met in January 2020 and have become an important addition to the policy-making nexus at this moment of national emergency. Its advice via publication of minutes, the involvement in the policy announcements of its members and their access to the media provides a critical clue as to how to proceed in improving economic and social policies. In the field of economic and social policy, too much still happens in a fragmented manner without a consistent approach in turning to experts, more one that replies on who is known already. There is clearly room for a more formal relationship in the area of national regeneration. The establishment of the Monetary Policy Committee in 1997 has demonstrated that expertise cannot only improve policy but also within well understood definition of goals and instruments achieve better outcomes. The establishment of the Industrial Strategy Council in 2018 and earlier the National Infrastructure Commission in 2015. As well as the Office for Budget Responsibility in 2010 provide some further clues on how this might work.

But if we look at the Department for Economic Affairs (1964-1969) through to the Gordon Brown's establishment of the short-lived, US-inspired National Economic Council in 2008, the history of independent economic scrutiny, operating within Government in the UK is not promising. Indeed, the 1992 creation of the Treasury Panel of Economic Forecasters, or the so-called 'Wise Men' does not augur well either. We need to move a little beyond these temporary fixes. In this case the British Academy, the Royal Economic Society, the Royal Statistical Society and the Royal Society and others, could be convened to establish a National Council on Economic Regeneration that could work as a way to assess policy for the long run, commission reports and ask the government to produce a view on the long run impact of policies of the income and regional distribution. Its objective would be to ensure the

\footnotetext{
${ }^{13}$ See NIESR Occasional Paper, No. 61, Ousting Budgetarians and re-establishing a Fiscal Policy, forthcoming, 2021. Also see H M Treasury, Final Report of the 2020 Green Book Review, 25 November 2020.

${ }^{14}$ See, for example, House of Commons (2014) on the role of the media in shaping the role and power of the Prime Minister.
} 
development and implementation of a regeneration plan by this and future governments using the knowledge of its broad membership to improve economic policy and planning, provide independent scrutiny and a set of experts for the media to develop strong links.

\section{Concluding remarks}

In this Commentary, I have tried to outline the severity of the problem faced by policymakers, building on my November essay (Chadha, 2020b). We need an urgent plan for national recovery and, as well as outlining how our approaches to the crisis of 2020 might have been improved with reference to social science, we need to ensure that we do a better job of harvesting and responding to the research and analysis of experts in the field. That will imply making those who hold public office more regularly accountable for their decisions and choices. Trial by media and by general election is neither sufficiently granular nor frequent.

The best we can hope for is that the two exits do not become amorphous and are used to leverage our full blown entry into a digital age, based on trade and comparative advantage, but where the constraints of unpromising initial conditions have been addressed systematically allowing us to deploy high levels of human, physical and intangible capital that will reap rewards for every section of society. There is so much to do.

Acknowledgements. I am grateful for conversations with Alan Barrett, Tiago Cavalcanti, Huw Dixon, Liam Halligan, Andrew Harvey, Hande Kucuk, Miltos Makris, David Miles, Adrian Pabst, Flavio Toxvaerd and for the weekly editorial meetings of the ESRC-funded Economics Observatory. Any remaining errors are mine. This Commentary was funded by an ESRC IAA grant and the work on fiscal policy by the Nuffield Foundation.

\section{References}

Ajzenman, N., Cavalcanti, T. and Da Mata, D. (2020), 'More than words: Leaders' speech and risky behaviour during a pandemic', Cambridge Working Papers in Economics CWPE2034.

Albornoz, F., Bradley, J. and Sonderegger, S. (2020), 'The Brexit referendum and the rise in hate crime; conforming to the new norm', Nottingham University CeDEx 2020-12.

Alloza, M. (2016), 'Is fiscal policy more effective in uncertain times or during recessions?' Centre for Macroeconomics Working Paper CFM-DP201631.

Ayoubkhani, D., Khunti, K., Nafilyan, V., Maddox, T., Humberstone, B., Diamond, I. and Banerjee, A. (2021), 'Epidemiology of post-COVID syndrome following hospitalisation with coronavirus: A retrospective cohort study', mimeo. DOI:10.1101/2021.01.15.21249885.

Besley, T. (2020), 'Better defining "levelling up" is a crucial step to achieving it', National Infrastructure Commission Blog, 6 November 2020.

Bhattacharjee, A. and Lisauskaite, E. (2020), 'Covid-19 impacts on destitution in the UK', National Institute Economic Review, 253, pp. R77-85.

Brewer, J.D. (2013), The Public Value of the Social Sciences: An Interpretative Essay, London: Bloomsbury.

Chadha, J.S. (2020a), 'Economics in a public health crisis', Science in Parliament, 76, 2, pp. 8-9.

Chadha, J.S. (2020b), 'The commentary: A country withered', National Institute Economic Review, 254, pp. F2-F3.

Chadha, J.S. and Dixon, H. (2020), 'Measuring GDP during a pandemic: Distortions from non-market health service output', Written Evidence, EIC0904-Economic impact of coronavirus, https://committees.parliament.uk/writtenevidence/18388/ pdf/.

Hansen, L.P. and Sargent, T.J. (2011), 'Wanting robustness in macroeconomics', in Friedman, B.M. and Woodford, M. (eds), Handbook of Monetary Economics, Volume 3B, Amsterdam: North-Holland, pp. 1097-1157.

Harvey, A.C. (2020), 'Time series models for epidemics: Leading indicators, control groups and policy assessment', NIESR DP, 517.

Holmes, P., Rollo, J. and Winters, L.A. (2016), 'Negotiating the UK's post-brexit trade arrangements', National Institute Economic Review, 238, 1, pp. R22-30.

House of Commons. (2014), 'Political and constitutional reform—first report role and powers of the Prime Minister', 19 June 2014.

Knight, F.R. (1921), Risk, Uncertainty and Profit, Boston and New York: Houghton Mifflin Company.

Low Pay Commission Report. (2020), 'National minimum wage', presented to parliament by the secretary of state for business, Energy and Industrial Strategy, January 2020. 
Lupia, A. (2017), 'Now is the time: How to increase the value of social science', Social Research: An International Quarterly, 84, 3, pp. 669-94.

Makris, M. and Toxvaerd, F. (2020), 'Great expectations: Social distancing in anticipation of pharmaceutical innovations', COVID Economics 56, 9 November.

Miles, D., Stedman, M. and Heald, A. (2020), 'Living with Covid-19: Balancing costs against benefits in the face of the virus', National Institute Economic Review, 253, R60-76.

National Audit Office. (2020), 'The government's approach to test and trace in England-interim report', Report by the Comptroller and Auditor General, HC 1070, Session 2019-2021, 11 December 2020.

NIESR Occasional Paper, No. 61, Ousting budgetarians and re-establishing a fiscal policy, forthcoming, 2021.

Office for Budget Responsibility. (2020), 'Economic and fiscal outlook-November 2020', Presented to Parliament by the Exchequer Secretary to the Treasury.

Parliamentary Office of Science and Technology (POST). (2020), Monitoring wastewater for COVID-19, https://post. parliament.uk/monitoring-wastewater-for-covid-19/, retrieved on Jan. 2021.

Policy Reform Group. (2019), 'Beyond brexit: A programme for UK reform', National Institute Economic Review, 250.

Ramdas, K., Darzi, A. and Jain, S. (2020), 'Test, re-test, re-test': Using inaccurate tests to greatly increase the accuracy of COVID-19 testing', Nature Medicine, 26, pp. 810-1.

Royal Society DELVE initiative. (2020), 'Economic aspects of the COVID-19 crisis in the UK', available online at https://rsdelve.github.io/reports/2020/08/14/economic-aspects-of-the-covid19-crisis-in-the-uk.html, retrieved on Aug. 2020.

Stamp, J.S. (1931), 'The report of the Macmillan Committee', The Economic Journal, 41, 163, pp. 424-35.

Venables, A.J. (2020), 'Winners and losers in the urban system', in Glaeser, E., Kourtit, K. and Nijkamp, P. (eds), paper in Urban Empires.

Cite this article: Chadha, J. S. (2021), 'Commentary: Whither after COVID-19 and brexit: A social science perspective', National Institute Economic Review, 255, pp. 1-8. https://doi.org/10.1017/nie.2021.3 